\title{
Die "verbondstruktuur" in die Nuwe Testament - 'n terreinverkenning met die oog op die debat oor die verhouding kinderdoop-verbond
}

\author{
AG VAN AARDE
}

\section{VOORAF OPMERKINGS}

Iets wat hom aan die Bybelwetenskap opdring, is die teenwoordigheid van die woord "testament" in beide benaminge "Ou Testament" en "Nuwe Testament". Die benaming "Nuwe Testament" as aanduiding van die een korpus boeke in die Bybel wat onderskei word van die ander een, die "Ou Testament", kom in Griekse en Latynse geskrifte eers tydens die wisseling tussen die tweede en derde eeu by onderskeidelik Klemens Aleksandrinus en Tertullianus voor. Daar word feitlik allerweë erken dat hierdie onderskeie benaminge korporatief die boeke van die "Nuwe Verbond" teenoor dié van die "Ou Verbond" wil aandui. Die woord/begrip "verbond" dring hom gevolglik, net soos "testament", ook aan die Bybelwetenskaplike op. 'n Nuwe-Testamentiese studie van dié woord/begrip is egter in velerlei opsigte problematies. Afgesien van watter hoek ook al van waaruit so 'n studie gedoen kan word, bied dit nie enkelvoudige resultate nie. Ons spits die onderhawige ondersoek toe op die teologiese verbande wat tussen die kinderdoopleer en die verbond gelê en in die Nuwe Testament gegrond word.

Soos by die reformatoriese vadere, vervul die "verbond" ook by Suid-Afrikaanse, reformatoriese teoloë 'n beslissende rol in die verdediging van die kinderdoop. Wat die anabaptiste betref, het die $\mathrm{Ou}$ Testamentiese konsep "verbond" met die koms van Jesus Christus uitgefaseer, en lewer die "verbond" dus op 'n negatiewe wyse vir hulle 'n bydrae ten gunste van die verwerping van die kinderdoop. Die "verbond" funksioneer egter ook op 'n positiewe wyse by 'n teoloog soos Karl Barth in sy verwerping van die kinderdoop. Dit blyk daarom dat Pont (1983: 16) volkome korrek was toe hy gesê het dat die kinderdoop staan en val by die leer van die verbond en alles wat dit impliseer. 
Ons is in hierdie ondersoek nie geïnteresseerd in die manier waarop die "verbond" in die anabaptiste se verwerping van die kinderdoop funksioneer nie, maar in die vraag na die legitimiteit van die gebruik van die Nuwe Testament as grond vir sowel die verwerping as die fundering van die kinderdoop wat positief gebaseer word op die woord/begrip "verbond". Ter wille van duidelikheid dien vermeld te word dat die kinderdoop op grond van Nuwe-Testamentiese getuienis onses insiens 'n aanvaarbare vorm van doop is. Gesien vanuit 'n bepaalde teologiese perspektief op die konsep "verbond", is dit op grond van verskillende faktore inderdaad vir die kerk vandag die logiese vorm van doop. Op hierdie aspek word daar in die onderhawige studie nie eksplisiet ingegaan nie. Die oortuiging dat die kinderdoop Nuwe-Testamenties regverdigbaar is, sal egter sterk geïmpliseer word.

Twee tipiese, maar debateerbare uitsprake in verband met die verbond met betrekking tot die doop, kom wyd verspreid in teologiese en kerklike kringe voor: (1) Die "begrip" verbond gaan terug op die voorkoms van die Hebreeuse "woord" $b^{e}$ rit in die Ou Testament, en hoewel hierdie Hebreeuse woord met verskillende Griekse woorde en vertalings-ekwivalente in die Septuagint weergegee is, is dit opmerklik dat die Septuagint, waar dit in die "begrip-verbond" om die verhouding tussen God en die mense gaan, dáár deurgaans die Griekse "woord" diathēke gebruik. (2) Die "begrip" verbond is een van die belangrikste teologiese temas, indien nie dié belangrikste nie, in die hele Bybel en dit funksioneer dikwels (wat die kinderdoopdebat betref, konsekwent), hermeneuties en heuristies as 'n soort "Beziehungsmitte" wat die antwoord op baie teologiese vrae bied. Die hantering van die "verbond" as 'n sentrale tema van die Bybelse boodskap, word selfs in die resente rapport van die "Faith and Order Commission" van die Wêreldraad van Kerke oor Skrifgesag aangetref. Dit is des te meer merkwaardig, omdat die WRK as ekumeniese liggaam juis in dié rapport ernstig besin oor onder andere die verband tussen die diversiteit van die Bybelse boodskap en die pluriformiteit van die kerk: "Covenant is one of the most central themes which bind together the two Testaments. First we are told of the covenant God made with the whole of creation through Noah; then comes the covenant with Abraham, father of all believers; next the covenant made through Moses with the people of Israel and renewed under Joshua and Josiah; with the rise of king David we hear of the covenant with the Davidic house and in the book of Jeremiah we meet the promise of the new covenant to be written on 
the hearts of men and not on tables of stone. Finally comes the culmination of this theme, the establishment of the new covenant in Jesus Christ" (Flesseman-van Leer 1980: 66v).

Dit is ons kritiek op die aard van sekere vooronderstellinge in die (Nuwe-Testamentiese) Skrifgebruik sowel as Skrifbeskouing, grondliggend aan bogenoemde twee uitsprake, wat kan veroorsaak dat die resultate en tese van ons studie deur sommige miskien as kontra-produktief vir die teologiese debat oor die regverdiging al dan nie van die kinderdoop beskou kan word. Ons vertrou egter dat die ondersoek wel 'n bydrae in dié debat kan lewer.

Die tese van ons studie is tweërlei van aard: Die fundering asmede die verwerping van die kinderdoop op grond van die "verbondsteologie" (1) vertoon dikwels 'n illegitieme vermenging van sowel filologie met teologie as filologiese kategorieë en argumente op sigself, en (2) getuig dikwels van positivistiese, nie-verantwoordbare teologiese uitbouing van semantiese en eksegetiese resultate. Hieruit voortspruitend beoog die studie om (1) 'n verklaring te bied vir die teenwoordigheid van die term testament in onderskeidelik die benaminge "Ou Testament" en "Nuwe Testament", (2) kortliks 'n oorsig te bied van die onderskeidende betekeniskomponente van die woorde in die Nuwe Testament wat semanties gesien met 'n "verbondsverhouding" te doen het, en (3) die teologiese kwessies nader te presiseer wat op grond van die "verbondsteologie" 'n rol in sowel die fundering as die verwerping van die kinderdoop vervul, met die oog op die toetsing daarvan aan die hand van Nuwe-Testamentiese getuienis. Hierdie evaluering vind as gevolg van die omvattendheid van die tersake onderwerp nie in hierdie studie plaas nie. Die bedoeling van ons ondersoek is dus primêr beskrywend en terreinverkennend van aard.

\section{DIE "VERBONDSTEOLOGIE" GRONDLIGGEND AAN KARL BARTH SE VERWERPING VAN DIE KINDERDOOP}

GC Berkouwer (eens een van Barth se skerpste kritici) betuig in sy dissertasie oor Karl Barth se verwerping van die kinderdoop instemming met AA van Ruler dat hoewel die term en die begrip "verbond" nie as 'n selfstandige "dogmatische figuur" in Barth se Kirchliche Dogmatik voorkom nie, dit "desniettemin door de motieven van de Verbondsleer geheel beheerscht wordt" (Van Ruler 1945: 75). Die konsep "verbond" is die "grondconceptie" van Barth se dialektiese teologie. Hiermee saam toon Van Ruler met 'n sitaat uit die $K D$ aan dat die "gratia praeveniens" (= die soewereine prae van die Goddelike genade 
ten opsigte van alle geloofsaktiwiteite van die mens) in Barth se teologie voorop staan (kyk Berkouwer 1947:106). Tog het Barth die kinderdoopleer verwerp. Wat sy verwerping daarvan uitermate interessant maak, is dat hy dit op grond van onder andere sy "verbondsteologie" gedoen het, terwyl die kinderdoopleer juis die "gratia praeveniens" so sterk wil beklemtoon. Berkouwer (1947: 108) meen daarom tereg dat ons te doen het met verskillende verbondsbeskouinge wat almal daarop aanspraak maak om Bybels te wees. Dit is teen hierdie agtergrond dat ons vervolgens gaan poog om enkele kwessies te identifiseer wat in die klassieke debat oor die verhouding kinderdoop-verbond Nuwe-Testamenties gegrond is, maar waarop die semantiek van Nuwe-Testamentiese Grieks en die eksegese en teologie van die Nuwe Testament onses insiens ' $n$ korrektief kan bied. Ons begin met 'n uiteensetting van die rol wat die "verbondsteologie" in Karl Barth se verwerping van die kinderdoop vervul. Eers nadat ons ook 'n kort, sistematiese samevatting van die aard van die "verbondsteologie" van sommige voorstanders van die kinderdoop in Suid-Afrika gebied en die semantiek van die verskillende Griekse woorde/uitdrukkinge in die Nuwe Testament, met betrekking tot ('n) "verbondsverhouding(e)" oorsigtelik bespreek het, word daar kortliks relevante, teologiese kwessies geabstraheer.

Barth se grondstelling in verband met die "wese van God" is terselfdertyd die uitgangspunt van sy siening oor die "verbond", naamlik dat God is wat Hy is in die daad van sy openbaring en dit is dat God gemeenskap tussen Homself en ons soek en skep: "Gott ist, der ist in der Tat seiner Offenbarung. Gott sucht und schaft Gemeinschaft zwischen sich und uns und so liebt er uns. Eben dieser Liebende ist er aber als Vater, Sohn und Heiliger Geist auch ohne uns, in der Freiheit des Herrn, der sein Leben aus sich selber hat" ( $K D$ II, 1, 288). Dit kom daarop neer dat reeds die skepping die "innere Grund" van die verbond is en dat die mens geskep en bedoel is om die bondgenoot van God te wees. Hierbenewens blyk, op grond van bovermelde sitaat, die korrektheid van Van Ruler se waarneming hierbo dat Barth in sy "verbondsteologie" uitgaan van die "gratia praeveniens": Die wese van God is sý wese, die daad van God is sý daad en die liefde van God is sý liefde (kyk $K D$ II, 1, 334). Barth (1947 b: 5) sê elders dat dit in die liefde van God gaan om die soek en skep van gemeenskap sonder dat daar by die mens ' $n$ aanknopingspunt as die gevolg van ' $n$ bestaande verbonds- en gemeenskapsgeskiktheid (Bündnis- und Gemeinschaftfähigkeit) bestaan. 
Soos daar geen ander God is as die Verbonds-God nie, so is daar ook geen ander mens as die verbonds-mens nie ( $K D$ IV, 1, 45). Om outentiek mens te wees, beteken om saam met God te wees: "Menschsein heisst: Mitt Gott zusammen sein" (KD III, 2, 167). Die geloof is die eis van God se verbond; ongeloof is bondsbreuk, want dit is die uitoefening van die keuse van die eie ongeloof wat meen om sonder God te wees (KD IV , 1, 122, 127). Barth formuleer dit soos volg: Die goddelike "ja" waarop die sonde "nee" sê, is die "ja" van die verbond van God met die mens wat reeds die geheimenis van die skepping is (KD IV, 1, 154). Versoening met God is die versoening van die onwaardige bondgenoot van God (Partner Gottes). Jesus Christus is die "teentrou" van die mens teenoor die "trou" van God, en daarom is Jesus Christus die vervulling van die verbond. "In Christus" is die gemeente ingesluit en "in Christus" en "in en met die gemeente" is ook die individu ingesluit (KD II, 1, 360). Dit is in hierdie verband wat Barth se uitdrukking "die verbond van God met die mens, Jesus Christus" (KD IV, 1, 46) geïnterpreteer moet word, asook die uitspraak dat Jesus Christus se menswording "das grosse christliche Mysterium und Sakrament" (KD IV, 2, 42) is.

Bogenoemde oorsigtelike opmerkings kan onses insiens as die grondstellings van Barth se "verbondsteologie" beskou word en kan aan die hand van die volgende drie punte saamgevat word (kyk ook Visser 1958: 30, 58, 64): (1) God is in sy wese Verbonds-God en die dade van sy openbaring is derhalwe verbonds-dade. (2) Deurdat die karakter van die verbond vanuit die wese van God bepaal word en nie vanuit òf die wese van die mens wat sondaar is òf 'n menslike behoefte aan die verlossing van God nie, is die verbond van God van begin tot end 'n saak van "monopleuriese" genadeverbond. (3) Omdat God "intertrinitaries" Verbonds-God is, moet die verhouding tussen God en die mens geïnterpreteer word in die lig van die verhouding en gemeenskap wat deur Jesus Christus as die "vervulling van die verbond" geskep is en deur die werking van die Heilige Gees in stand gehou word.

Al hierdie grondstellings het verreikende implikasies vir die fondamente en uitgangspunte van die reformatoriese kinderdoopleer (kyk later). Dit word dus meteen duidelik waarom die "verbondsteologie" grondliggend is aan Barth se verwerping van die kinderdoop. Eerstens kan hy die skolasties-geformuleerde onderskeid aan die een kant tussen die sogenaamde "werkverbond" en "genadeverbond" (kyk Heyns 1978: 207-15) en aan die ander kant tussen die "algemene" en "beson- 
dere" genadeverbond (met sy sogenaamde historiese ontwikkeling vanaf Adam tot Noag, vanaf Noag tot Abraham, en vanaf Abraham deur Israel tot Jesus Christus en die uitstorting van die Heilige Gees) nie aanvaar nie. Tweedens het daar mettertyd in sy denke 'n verskuiwing met betrekking tot die reformatoriese (Calvinistiese) sakramentsbeskouing plaasgevind. Ons gaan vervolgens baie kortliks in op enkele aspekte hiervan, sowel as die kontekstualiteit waarbinne dit plaasgevind het.

Dit is volgens Barth (1948: $95 \mathrm{v}$ ) volkome korrek om te sê dat die kind deel is van die verbond, maar daar is volgens hom ' $n$ verskil tussen die deelhê aan die genadeverbond en die insluiting in die gemeente van God. Die individu wat in die gemeente ingesluit is, is "in Christus", die "vervulling van die verbond" (kyk weer hierbo). En op grond van onder andere Rom 6:1-14 is die doop die "Abbild" van hierdie werklikheid (1947a: 8), naamlik dat die mens op grond van die geloof deel het aan die dood en opstanding van Jesus Christus. Dit is met ander woorde nie net Jesus Christus alleen wat gesterf en opgestaan het nie; in Hom het ook die mens wat deur die krag van die Heilige Gees met Jesus Christus tot één liggaam verbind is, gesterf en opgestaan. Die doop is die "Abbild" van die "ja"-antwoord van die mens as "bondgenoot" op die inisiatief van God; dit is derhalwe die "Abbild" van die "teentrou" van die mens "in Christus" (KD IV, 1, 19; 59v). Die doop moet daarom bedien word aan dié wat daarvoor vra, want die doop is 'n "bekragtiging" ("Bestätigung") van die geloof (Barth 1948: 87v; 91v). Die dopeling moet dus sy geloof kan bely en 'n kind kan dit nie doen nie (vgl Visser 1958: 95). Die konsekwensie van Barth se standpunt is dat die kind voorwerp van die genadeverbond is en daarom die belofte van die Heilige Gees ontvang het, maar omdat hy nie sy geloof kan bely nie, is die kind nog nie lid van die gemeente nie. Die doop behoort daarom nie aan die kind bedien te word nie.

Die feit dat die genadeverbond kindertjies insluit, regverdig met ander woorde volgens Barth nie die kinderdoop nie. Die kinders is ook nie prinsipieel voorwerpe van die verbond, omdat hulle ouers dit is nie. Hulle is voorwerpe van die verbond, omdat alle mense dit is. Die onderskeid in die gereformeerde skolastiek tussen die sogenaamde "algemene" en "besondere" genadeverbond (kyk Louis Berkhof 1946: 284) kan daarom ook nie volgens Barth ingespan word om die kinderdoop te help fundeer nie. Hierdie onderskeid word soos volg met betrekking tot die plek van kinders in die genadeverbond toegepas: "... in die algemene genadeverbond (is daar) diegene ... wat later tot 
geloof kom en blyk van die besondere genadeverbond te wees. So word daar ook binne die besondere genadeverbond kinders gebore wat later blyk ongelowiges te wees ..." (Visser 1958: 349). Die argument om op grond van só ' $n$ onderskeid die kinderdoop te regverdig, is in der waarheid volgens Barth irrelevant (vgl König 1971: 120). Hy gee toe dat die kinders van gelowiges volgens Hand 2:39 en 1 Kor 7:14 onderskeibaar is van die kinders van ongelowiges (KD IV, 4, 197-202). Die uitspraak in 1 Kor 7:14 dat die kinders van gelowiges "heilig" (nav: "behoort ... aan God") is, beteken egter nie dat hulle belydende lidmate van die gemeente is, of dat gelowige ouers die oorsaak van geloof by hulle kinders is nie. Die taak van die ouers is om die "naaste" van hulle kinders te wees. Die kinders word deur hulle gelowige ouers na die vaderskap van God gerig, na die genadeverbond van God in Jesus Christus (KD III, 4, 275). 1 Kor 7:14 kan daarom nie gebruik word om die kinderdoop te regverdig nie (vgl König 1971: 121v). Net so min as dat die ongelowige huweliksmaat, waarna hierdie Skrifgedeelte ook verwys, op grond van die "heiliging" (hagiazō) deur sy gelowige maat, 'n Christen is en gedoop behoort te word, so min behoort kinders op grond van die "heiliging" deur hulle gelowige ouers gedoop te word. Volgens Barth bestaan daar nie so iets soos 'n "fides aliena" nie. Op grond van Heb 12:2 is Jesus, "die Begin en die Voleinder van die geloof", die enigste wat 'n outentieke plaasbekledende geloof gehad het. Eweneens is daar nie iets soos 'n "fides infantiles" nie; dit is waarom die kinderdoop volgens Barth na vervollediging in die "openbare belydenis van die geloof" ("konfirmasie") roep sodat die moment wat in die doop uitgeval het, weer ingehaal kan word. Insgelyks kan die afleiding nie op grond van Hand 2:39 gemaak word dat kinders van gelowige ouers die "Christelike lewe" erf nie. Hulle "Christelike lewe" kan alleen op grond van God se bevryding wat hulle self in hulle eie geloofsbeslissings ervaar, ' $n$ aanvang neem. In die plek van die kinderdoop behoort ' $n$ "kerklike wyding" van kindertjies te kom, sodat tekste soos Mark 10:15 en Matt 18:3 volgens Barth tot hulle reg sal kom.

Die feit dat Barth die doop as uitsluitlik menslike daad só in verband met die monopleuriese genadeverbond van God sien, roep by ons die vraag op na sy beskouing oor die sakramentele karakter van die doop en daarom uiteraard na die verhouding besnydenis-doop. Volgens König (1971: 123) moet Barth se verwerping van die kinderdoop waarskynlik daaraan toegeskryf word dat hy die sakramente nie binne die kader van die verbondsteologie bedink het nie. Die gevolg was dat 
Barth sedert $K D$ IV, 4 die doop as sakrament nie meer gehandhaaf het nie, maar dit konsekwent as deel van die etiek behandel het.

Aanvanklik het Barth (1947a: 23v) wel gemeen dat die doop in die plek van die besnydenis gekom het, maar dat Israel versamel is deur die bande van bloed en familie (daarom die besnydenis), terwyl die kerk versamel word deur die geloof. Reeds van dié tyd af het Barth gemeen dat die belydenis van die geloof en die uitgesproke wens deur die dopeling om tot die Christelike gemeente te behoort, 'n onontbeerlike element van die Christelike dooppraktyk behoort te wees (vgl ook Visser 1958: $140 \mathrm{vv}$ ). Later het hy oorgegaan tot selfs die ontsakramentalisering van die doop. Vanuit sy siening dat Jesus Christus se menswording "das grosse christliche Mysterium und Sakrament" is en dat daar streng gesproke geen ander sakrament daarbenewens kan wees nie (KD IV , 2, 42), sê hy in verband met die doop: "Die Taufe ... ist aber nicht Gnadenträger, nicht Gnadenmittel, nicht Instrument der Gnade. Die Taufe antwortet auf das eine "Mysterium", das eine "Sakrament", der Geschichte Jesu Christi, seiner Auferstehung, der Ausgiessung des Heiligen Geistes: sie selbst ist aber kein Mysterium, kein Sakrament" (KD IV, 4, 112; kyk ook König 1971: 44v).

Die wyse waarop Barth hierdie ontsakramentalisering van die doop op grond van sy eksegese van tekste soos Hand 22:16; Heb 10:22; Ef $5: 25 \mathrm{v}$ grond, toon dat hy kruis sien as respektiewelik God se beslissende handeling teenoor die doop as die mens se beslissende handeling. Hiermee ontken hy dat die doopgebeure die sakramentele representasie van die kruisgebeure kan wees. Dit is onder andere teen hierdie agtergrond waarteen Barth se kritiek op die beklemtoning in die reformatoriese teologie (kyk Heidelbergse Kategismus, vraag en antwoord 72) verstaan moet word dat die doop die verseëling is van God se beloftes, in die sin van "bevestiging" en "toesegging". Hiervolgens kan die doop vóór die geloof van die dopeling bedien word en kan die geloof eers daarop volg. Barth vra hierteenoor (vgl ook König 1971: 123) of die belofte van God nie alreeds deur die Heilige Gees vir elke mens (ook vir die ongedoopte) vasstaan nie. Wat volgens Barth nodig is, is nie nóg 'n "bevestiging" van die belofte nie, maar mense wat die belofte van die verbond in geloof aangryp. Só gesien is die geloofsbeslissing van die mens as die "ja" op die belofte van die genadeverbond, ' $n$ beslissing van die mens "in Christus" - Jesus wat as die "teentrou" van die mens teenoor die "trou" van God die vervulling van die verbond is. Die doop is die "Abbild" van hierdie werklikheid. Indien die doop slegs die belofte van die verbond sou beteken en 
verseël, is dit volgens Barth funksieloos, want die belofte van die verbond is in die lig van die "inter-trinitariese" werk van God klaar deur die werking van die Heilige Gees, sonder die doop, verseël.

As iemand die oorlogsgebeure in Europa (veral tussen 1930-1940) nie in hierdie verband in ag neem nie, sal hy nie werklik insig hê in die historiese kontekstualiteit waarbinne Barth die (kinder)doop finaal geontsakramentaliseer en verwerp het nie. Die teologiese besinning binne hierdie politieke konteks wat in Duitsland grotendeels bepaal was deur Hitler se oorname van die Duitse Kerk, het uitgeloop op onder andere Barth se kontroverse met bekende teoloë. Hierdie dispute het regstreeks verband gehou met sy verwerping van die kinderdoop en die ontsakramentalisering van die doop as sodanig.

Die kontrovers met Gerhard Kittel het gehandel oor die problematiek met betrekking tot die sogenaamde "skeppingsteologie" en veral oor die verhouding "skepping"-"verlossing". Hierdie teologiese kwessie het as politieke agtergrond die Nasionaal-Sosialisme se beroep op die oerkategorieë van die skepping, naamlik bloed en ras (gesin, familie en volk) en bodem as gawes van God (vgl Berkouwer 1947: 113). Dié met Freidrich Gogarten het betrekking gehad op Gogarten se standpunt wat hy rondom 1933 rakende die beweging "Deutsche Christen" ingeneem het (vgl Berkouwer 1974: 69v). Barth se lewenslange vriend en medevader van die dialektiese teologie, Rudolf Bultmann, is ook skerp deur hom aangespreek omdat Bultmann bereid was om die voorgeskrewe deklarasie van onderhorigheid deur Duitse akademici aan Hitler te onderteken (vgl Jaspert 1981: 78v).

Hierdie kontroverse toon dat Barth se kritiek op die kinderdoop, op grond van sy siening dat daar 'n radikale verskil is tussen die "natuurlike heiliging van die geslagte van Israel" (bloed en bodem) teenoor die "geboorte uit God" (die geloofsbeslissing van die individu "in en met die gemeente"/"in Christus"), ten nouste in verband staan met sy besware teen die "volkskerk"-motief. Berkouwer (1947: 110v) meen dat Barth van oortuiging was dat die kinderdoop 'n "volksmassa-kerk projectie" was. Net soos Van Ruler (1945: 85v) sien Berkouwer (1947: 41-51) Barth se kritiek op die "volkskerk"-konsep as die agtergrond waarteen Barth sy visie op die kinderdoop met die vroeëre dogmenhistoriese "corpus Christianum"-vraagstuk in verband gebring het. Barth het rondom 1935 hierdie vraagstuk indringend begin bespreek (kyk o.a. Barth 1936, aangehaal deur Berkouwer 1947) en hy het dit op sy stryd teen die sogenaamde "natuurlike teologie" toegepas. Dit het dus die grond help bied waarop hy so 'n ingrypende "struktuurverskil" 
tussen Israel (in die Ou Testament) en die kerk (in die Nuwe Testament) geponeer het. "Israel" sou volgens hom bestempel kan word as 'n gemeenskap van die "natuurlike", van "bloed en bodem" (en hierop het die Ou-Testamentiese besnydenis betrekking), terwyl die "kerk" 'n geloofsgemeenskap is, "gebore uit God" (en hierop het die NuweTestamentiese doop betrekking (vgl Berkouwer 1947: 21). "De felle reactie tegen de 'scheppingstheologie' leide hem niet alleen tot verwerping van artikel 3 der Geloofsbelijdenis, maar ook tot de ontkenning van de constitutieve beteekenis van het gezin voor het Verbond en zag ten onrechte den kinderdoop in hetzelfde vlak als het 'doopen' van een geheel volk desnoods zonder persoonlijke beslissing des geloofs. Hij zag, in dien kinderdoop een naturaliseering van het verbond" (Berkouwer 1947: 134).

Volgens Berkouwer (1947: 133) was hierdie vraagstuk oor die verhouding tussen die (Ou-Testamentiese) volk Israel en die (Nuwe-Testamentiese) kerk, oftewel die dogmatiese vraagstuk oor die verhouding skepping-verlossing, die oorsaak dat Barth "tenslotte zelfs het 'gratia praeveniens'-motief in verband met den kinderdoop uit $z^{\prime} n$ voegen rukte".

\section{DIE “VERBONDSTEOLOGIE" GRONDLIGGEND AAN DIE FUNDERING VAN DIE KINDERDOOP}

Net soos by Karl Barth, is die begrip "verbond" by Suid-Afrikaanse teoloë wat in die onmiddellike verlede oor die verhouding verbondkinderdoop geskryf het, die grondstruktuur van sowel die teologie as die totale Bybelse boodskap. Insgelyks is die meeste motiewe wat prominent in Barth se verbondsteologie funksioneer, ook by dié teoloë belangrike kwessies. Dit word egter, wat sekere aspekte daarvan betref, radikaal verskillend geïnterpreteer. A König (1983) het in hierdie verband, sover my kennis strek, die omvattendste studie gedoen en ons volg derhalwe, ten einde 'n blik op die funksionering van die verbondsteologie as fundering van die kinderdoop te kry, die basiese raamwerk van sy betoog. Ons verwys in die kort uiteensetting daarvan telkens ook na die parallelle insette wat AD Pont (1983), WD Jonker (1984) en BJ Engelbrecht (1983) in hierdie verband gelewer het.

Daar bestaan onder die gemelde geleerdes konsensus dat die begrip "verbond" 'n "redelike sentrale perspektief op die Bybelse boodskap" (König 1983: 1) is (kyk ook Jonker 1984: 7; Engelbrecht 1983: 1 en Pont 1983: 5). In die woorde van Pont is die verbond, hoewel dit één van die 
beelde is wat in die Bybel gebruik word om die verhouding tussen God en mens te beskryf, op grond van die motiewe wat in hierdie begrip voorkom, duidelik 'n struktuur van die teologie as 'n gehéél! Die aard van hierdie "teologiese struktuur" word deur Engelbrecht, grondliggend vanuit 'n tota Scriptura en heilshistoriese visie (sonder dat hy dié visie eksplisiet noem of uitspel), samevattend beskryf. Volgens Engelbrecht gaan die begrip "genadeverbond" terug na die verbond tussen God en Abraham. Hierdie "verbond" is 'n ewige genadeverbond in onderskeid met die "Noagverbond" en die "Sinaiverbond". Die verbondsteken van die "Noagverbond" is die reënboog teenoor die besnydenis as verbondsteken van die "Abrahamverbond". Jer 31:31-34 praat van 'n "nuwe verbond", as 'n voortsetting van die "ewige genadeverbond met Abraham". Volgens Heb 10:16 is Jesus Christus die middelaar van hierdie nuwe, beter verbond en op grond van Gal 6:16 kan geponeer word dat die "heilsbeloftes" van God se "ewige genadeverbond met Abraham" ook vir die Nuwe Testament se "Israel van God" dieselfde bly. Die enigste verskil in hierdie verband tussen die $\mathrm{Ou}$ Testament en die Nuwe Testament is die teken van die verbond: die besnydenis as teken van die "ou verbond" vir die Ou-Testamentiese bondsvolk en hulle klein kindertjies teenoor die doop as teken van die "nuwe verbond" vir die Nuwe-Testamentiese bondsvolk en hulle nageslag. Die kinders van Christengelowiges het daarom deur Christus deel aan dieselfde verbondsbeloftes en verbondsteken as waaraan die verbondskinders van die "ou verbond" deelgehad het.

By wyse van afleiding uit bogenoemde kompakte beskrywing van die verhouding kinderdoop-verbond, kan die volgende drie sake geidentifiseer word wat ons ten opsigte van sekere aspekte, asmede temas uit Barth se "verbondsteologie", vanuit 'n semantiese, NuweTestamentiese en Bybels-teologiese perspektief 'n korrektief kan bied.

(1) Daar word met die begrip "verbond" op só 'n manier omgegaan asof dit presies dieselfde is as die woord $b^{e}$ rit (in die Ou Testament) èn die woord diathēke (in die Nuwe Testament) (kyk Jonker 1984: 7; König 1983: 24; Pont 1983: 5v; vgl ook Heyns 1978: 202). Daarbenewens word daar ook geteologiseer oor "motiewe"/"theologoumena" wat verband sou hou met die "begrip/woord" be rit - diath $\bar{e}$ $k \bar{e}$, soos monopleurisme, verbondsbeloftes, verbondstekens, Israelkerk as volk van God, geloof, genade, ensovoorts.

(2) Die begrip/woord "verbond" (besonderlik: die genadeverbond met Abraham) en bogenoemde motiewe word as ' $n$ "teologiese struktuur" hanteer en beskryf wat, Bybels-teologies gesien en soos 
vroeër reeds vermeld, die sentrale tematiek van die Bybel sou wees. König (1983: 14), formuleer dit soos volg: "Hierdie verbond loop soos 'n goue draad deur (die Ou Testament - AG v A) tot in die Nuwe Testament, word bekragtig deur die offer van Christus en vind sy finale gestalte op die nuwe aarde (Op 21: 3v)."

(3) As sentrale tematiek funksioneer die woord/begrip "verbond" hermeneuties as 'n "Beziehungsmitte" van waaruit sekere Bybeltekste in 'n heilshistoriese, Bybels-teologiese raamwerk met mekaar gekoppel word om hulle "betekenis" èn die aard van die struktuur "verbond" vanuit hierdie binding te vind (vgl die koppeling vanaf Gen 17 tot en met Jer 31 wat gesiteer word in Heb 10, gekoppel aan Ga1 6 en selfs aan Op 21). Die toepassing van so 'n teologieshermeneutiese model met die oog op die fundering van die kinderdoopleer vestig die aandag op die volgende twee apriorieë, grondliggend aan dié fundering: enersyds die éénheid van die $\mathrm{Ou}$ Testament en die Nuwe Testament, en andersyds die éénheid tussen Israel (die volk van God in die Ou Testament) en die kerk (die volk van God in die Nuwe Testament). Met sulke apriorieë is dit vanselfsprekend dat die opvatting gehuldig word dat die aard van die teologiese struktuur van die genadeverbond met Abraham nie in die Nuwe Testament verander het nie, behalwe die verbondsteken: die besnydenis teenoor die doop. So gesien word die éénheid van die Ou Testament en die Nuwe Testament geskend as, by wyse van voorbeeld (kyk Pont 1983: 4), eerstens die Ou-Testamentiese genadeverbond in die Nuwe Testament sou oorgaan in 'n "testament-struktuur" waar die gelowige aan die nagelate erfenis van Jesus Christus se kruisgebeure deelkry, en tweedens die korporatiewe karakter van die verbond (met Abraham en sy nageslag) met ' $n$ individualisme vervang sou word.

Ons bied vervolgens 'n uiteensetting van (1) König se argumente (met die klem op Skrifgebruik) vir die positiewe kontinuiteit tussen die $\mathrm{Ou}$ Testament en die Nuwe Testament, gesien vanuit God se verbond met Abraham, en (2) die logosentriese beroep op die woord diath $\vec{e} k \vec{e}$ :

König se argument rondom die éénheid van die Ou Testament en die Nuwe Testament, met betrekking tot die verhouding kinderdoop-verbond, bestaan basies uit drie punte: Israel as God se volk van die $\mathrm{Ou}$ Testament fundeer die Nuwe-Testamentiese kerk; die korporatiewe karakter van die genadeverbond, en die onhoudbaarheid van die reglynige gelykstelling van die begrip "ou verbond" met die "Ou Testament" as sodanig. 
Wat die eerste argument betref, betoog König (1983: 4-7) dat die heidene volgens die Nuwe Testament aandeel aan die heil kry deur in Israel ingelyf te word. Sodoende kry hulle deel aan die verbond en verbondsbeloftes van God. Dit hou in dat Israel as die volk van God in die Ou Testament die Nuwe-Testamentiese kerk fundeer. König vind hiervoor die volgende skriftuurlike gronde: (1) Die getal twaalf in die aantal dissipels wat Jesus geroep het, asook in die sogenaamde latere aanstelling (sic) van die twaalf apostels. (2) In die Johannes beeldrede oor die goeie herder is "die skape van die goeie herder" die Joodse gelowiges en die "ander skape", wat nog deel van die één kudde (Jode èn heidene) sal word, die heidene. Hand 2 se berig oor die toestroming van alle volke in Jerusalem bied dit aan as klaarblyklik ' $n$ vervulling van die profetiese toekomsverwagting (o.a. Jes 2; Miga 4; Sag 8:20-23) dat al die volke rondom Israel na Jerusalem sal stroom om hulle met Israel te verenig. (3) Paulus gebruik in Rom 9-11 (kyk veral Rom 11:16-24) die beeld van die olyfboom vir die "blywende en onvervangbare betekenis van die Ou-Testamentiese Israel" (König 1983: 5): die stam van die boom is Israel; die takke is die gelowiges uit die Jode èn die heidene; hierdie takke wat uit en op 'n stam groei, is die NuweTestamentiese kerk wat op die Ou-Testamentiese "kerk" groei; die heidene is die wilde takke wat van 'n wilde olyfboom afgebreek en op die mak olyfboom ingeënt is. (4) In Ef 2-3, wat handel oor die versoening met God, word op die verhouding tussen die Jode en die nie-Jode in die gemeente ingegaan. Die Jode is diegene wat "naby" is en die nie-Jode diegene wat "ver" was (Ef 2:17). Hiermee sê die Efesiërbrief dat die nie-Jode uitgesluit was van die verbond met Israel en die verbondsbeloftes, maar op grond van die versoening met God saam met die Christen-Jode mede-erfgename van Israel se erfenis, mede-lede van Christus se liggaam en mede-deelgenote aan God se beloftes vir Israel geword het (Ef 3:6). (5) Dieselfde "begrippe" ("woorde"?) wat in die Ou Testament met betrekking tot Israel gebruik is, word in die Pauliniese briewe op die kerk toegepas, byvoorbeeld gemeente van God (qāhäl Jahwe) (sic), heiliges, uitverkorenes, geliefdes en geroepenes.

Wat die éénheid tussen die $\mathrm{Ou}$ Testament en die Nuwe Testament met betrekking tot die korporatiewe karakter van die genadeverbond betref, het König (1983: 7-11) se argument (die tweede hierbo) twee kante. Enersyds sê hy dat gelowiges se kinders ook deel het aan die verbond waarin hulle ouers opgeneem is en daarom die teken van die verbond behoort te ontvang. Andersyds dat ' $n$ groot deel van die vroeë 
kerk uit Jode bestaan het wat syns insiens God se geskiedenis met hulle sou verloën as hulle hulle kinders ná Christus uit die verbond sou uitgelaat het. König beroep hom soos volg op die Skrif as grond vir sy stellings: Die verbond met Abraham en die beloftes aan hom en sy nageslag word in die Nuwe Testament, nieteenstaande die ongunstige uitsprake oor Israel wat soms voorkom, altyd positief waardeer vanuit die hoek dat Abraham die vader van die verbond en die vader van alle gelowiges is. Hiervoor getuig die Sinoptiese Evangelies (Matt 8:11; Luk 16: 19-31), die Johannesevangelie (Jh 8: 37-40), die Jakobusbrief (Jk 2: 21vv), die Hebreërbrief (Heb 11: 8-19) en ook die Pauliniese briewe (o.a. Rom 4: 1-9 en Gal 3: 27, 29).

König pas sy eksegese van Rom 4, van waaruit hy retrospektief ook die verbondsluiting met Abraham in die Genesisboek interpreteer, soos volg op die verbondsleer en die korporatiewe karakter daarvan toe: Paulus gebruik Abraham as die "klassieke" voorbeeld dat redding alléén deur die geloof moontlik is. Die besnydenis was vir Abraham 'n "geloofsakrament". Die besnydenis is met ander woorde 'n "teken of seël" wat Abraham eers ontvang het nadat hy geglo het. (Vergelyk Rom 4:11 - kai sēmeion elaben peritomēs, sfragida tēs dikaiosunēs tēs pisteōs tēs en $t \bar{e}$ akrobustia ...) Hierdie sakrament was 'n "teken van bevestiging en 'n waarborg" dat Abraham regverdig verklaar is, omdat hy geglo het. Die afleiding wat hieruit gemaak kan word, is dat Abraham die vader is van alle gelowiges (besnedenes en onbesnedenes = Jode en nie-Jode). Hierbenewens versterk die uitdrukking seël van die geregtigheid van die geloof volgens König vanselfsprekend die indruk dat daar 'n verband tussen die besnydenis en die doop bestaan. "Immers ook die doop verseker 'n mens dat God jou aanneem omdat jy glo ... Hierdie uitspraak plaas die besnydenis in 'n direkte en positiewe verband met die geloof en die genadeverbond ... ons moet eenvoudig aanneem dat dit inderdaad in die genadeverbond so werk: gelowiges se kinders het ook deel aan die verbond waarin hulle ouers opgeneem is, en behoort die teken van hierdie verbond te ontvang" (König 1983: 10v).

Net so 'n "opvallende verband tussen doop en besnydenis" vind König (1983: 8) in Gal 3:27, 29. (Vergelyk vss 26-27-pantes gar huioi theou este die tês pistēos en Christō Ièsou. Hosoi gar eis Christon ebaptisthète, Christon enedusasthe. Vs 29 - ei de humeis Christou, ara tou Abraam sperma este, kat epangelian klēronomoi.) Hierdie Skrifgedeelte dui vir hom daarop dat die doop die gelowiges in die Abraham-verbond inlyf (vs 29) en dat dit ' $n$ vereniging met Christus is (vs 27). Daar is ook 
volgens König op grond van Gal 3-4 geen regverdiging vir die onderskeid wat in die verbondsleer gemaak word tussen die genadeverbond en die sogenaamde "nasionale verbond" waaraan die besnydenis gekoppel sou wees nie. (Kyk weer die bespreking van Karl Barth se verbondsteologie.) Daar is dus volgens hom nie bestaansgrond vir die beskouing van die teenstanders van die kinderdoop dat die "nasionale verbond" in die Nuwe Testament uitgefaseer het en dat net die genadeverbond geldig gebly het nie. Hy grond sy argument daarop dat die drie "basiese elemente" wat by die instelling van die verhouding in Gen 12, Gen 15 en Gen 17 telkens aanwesig was, naamlik "verhouding met God", "land" en "nageslag", in Op 21-22 direk gekontinueer is. Die twee "verbonde" waarna Gal 4: 21-5:1 verwys waarvan die een (gesimboliseer deur Hagar en Ismael) verval het en die ander een (gesimboliseer deur Sara en Isak) in die "nuwe verbond" ("Nuwe Testament") gekontinueer is, het te doen met Paulus se bestryding van die dwaling onder die Galasiërs wat die onderhouding van die wet as heilsweg beskou het.

Bogenoemde Skrifberoep bring ons by die volgende aspek van König (1983: 12-14) se betoog, naamlik dat dit volgens hom nie korrek is om die ou verbond sonder meer gelyk te stel met die Ou Testament as sodanig nie. Hierdie dispuut moet gesien word teen die agtergrond van eweneens die opvatting by sommige teenstanders van die kinderdoop dat daar 'n diskontinuïteit tussen die "ou verbond" en die "nuwe verbond" is. Die "ou verbond" is dan die Ou Testament en die "nuwe verbond" die Nuwe Testament. Dit sou meebring dat die hele Ou Testament, insluitende die verbond met Abraham, afgeskaf is en die doop derhalwe nie meer met die besnydenis in verband gebring kan word nie, of gesien kan word as 'n inlywing in die Abrahamverbond nie. König grond sy beswaar teen hierdie opvatting soos volg op die Skrif: Waar die "begrip/woord" ou verbond in die Nuwe Testament voorkom (kyk Heb 8: 5vv; Luk 22: 20 par; 2 Kor 3: 6vv) verwys dit na die Sinaïverbond/wetgewing en vermoedelik na die "verkeerde betekenis en gebruik wat Israel daaraan gegee het" (König 1983: 12), naamlik dat hulle die wet as heilsweg aangegryp het in plaas van as lewensreël vir die gelowige volk van God. Heb 9:15 beklemtoon dat Christus die middelaar van die "nuwe verbond" is - dié verbond wat spreek van verlossing alleen deur die bloed van Christus, van genade en sondevergifnis. Omdat die gelowiges in Christus volgens Gal 3: 15, 26v in die Abrahamverbond ingelyf is, is daar klaarblyklik ' $n$ ooreenkoms tussen die "nuwe verbond" en die Abrahamverbond (König 1983: 13). König 
verklaar Heb 9: 15 met ander woorde in terme van Gal 3: 15, 26 v. Hy beroep hom in die verband ook op Jer 31: $31 \mathrm{v}$ en konkludeer soos volg: "Daar is dus ' $n$ opvallende ooreenkoms tussen die inhoud van die nuwe verbond en die Abrahamverbond. In wese is dit dieselfde genadeverbond, die hart van die evangelie wat God reeds met Abraham gesluit het en deur die dood van Christus bekragtig word. Daarom is dit verkeerd om ongenuanseerd die Ou Testament die ou verbond te noem, en die Nuwe Testament die nuwe verbond. 'n Mens sou eerder kan sê die ou verbond is die (verkeerd geïnterpreteerde) Sinaï-wetgewing (kortliks: die wet) en die nuwe verbond is die Abrahamverbond wat deur die dood van Christus bekragtig is ... Dit is eenvoudig verkeerd om te sê die Ou Testament is afgeskaf en verby ... Veel eerder moet ' $n$ mens dus in die Ou Testament 'n onderskeiding aanbring. Die Abrahamverbond is, die genadeverbond waarin mense net deur die geloof opgeneem word" (König 1983: 13v).

Daar word onder andere twee sake by die fundering van die kinderdoop spesifiek op die semantiek van die Griekse woord diathēkē in die Nuwe Testament gebou, te wete die monopleuriese aard en die testament-karakter al dan nie van die verbond. Wat laasgenoemde saak betref, is die gevaar van illegitieme vermeninging tussen semantiek op sigself en teologie wesenlik, veral wanneer gelet word op die twee uiteenlopende wyses waarop onderskeidelik König en Pont die "semantiek" van diathēkē beredeneer om dieselfde teologiese saak te fundeer. Beide beklemtoon die feit dat die eenrigtingverkeer in die genadeverbond vanaf God na die mens toe die fundering is van die kinderdoop as teken en seël van die verbond en sy beloftes en dat die kinderdoop op grond hiervan in der waarheid die logiese vorm van doop is. Die uiteenlopendheid in die beredenering is dat aan die een kant dit juis die betekenis "testament" waarvoor die Griekse woord diathēkē dikwels diens doen, is wat op die monopleuriese aard van die verbond dui (König 1983: 24) teenoor aan die ander kant die standpunt dat die juridiese woord "testament" as betekenismoontlikheid van diathēkē afgewys moet word, "ondanks die gebruik van die beeld deur Paulus (Gal 3: 15 en Heb 9: 15), ... omdat die regsvorm van die testament onbekend by die Jode was" (Pont 1983: 5).

Dit is duidelik dat die monopleuriese komponent in die betekenis van die woord diathe $\bar{k} \bar{e}$ in die Septuagint en die Nuwe Testament, naamlik dat die beslissende inisiatiewe in die verbondsverhouding van God uitgaan, 'n belangrike argument vir die handhawing van die kinderdoop is. Die gemeenskaplike veronderstelling in die bovermelde 
uiteenlopende beredeneringe is dat die beroep op die woord diathe $\bar{e} \overline{\bar{e}}$, semanties gesien, logosentries van aard is. Dit kom daarop neer dat diathe $\bar{k} \bar{e}$ gesien word as die normale woord in die Septuagint en die Nuwe Testament wat vir die verbondsverhouding tussen God en mens gebruik is. Jonker (1984: 7) se formulering is derhalwe tipies: "Die begrip 'verbond' is 'n vertaling van die Heb beriet. Dié begrip kan gebruik word by 'n plegtige ooreenkoms tussen twee mense, met beloftes van wedersydse trou en afsprake dat, indien een van die partye ontrou aan die beloftes word, die oordeel van God hom sal tref. Opmerklik is dit dat die Griekse vertaling van die OT vir die verbondsbegrip, as dit om die verhouding tussen God en die mense gaan, deurgaans die begrip 'diatheke' gebruik, wat eintlik eerder 'testament' of 'insetting' of 'beskikking' beteken en nie soseer ooreenkoms of 'kontrak', soos wanneer dit om die verbond tussen mense gaan nie. Vir lg word meestal die begrip 'suntheke' gebruik." Die verskil is duidelik, sê König (1983: 24) in dieselfde trant: "In 'n testament word alles van een kant af bepaal - en die ander kant kan net aanvaar wat bepaal is". König gebruik die bekering van Paulus as 'n "belangrike voorbeeld" van die "voortgesette" (vanaf die Ou Testament na die Nuwe Testament - AG v A) karakter van die verbond: "God se inisiatief en Paulus se reaksie ... in Paulus se geval vertoon die verbond dus nog steeds die struktuur waarin die kinders van gelowiges sinvol opgeneem kan word" (König 1983: 25).

Indien die Griekse woord diathêke ook "testament" sou beteken, is die deur heelwaarskynlik volgens Pont (1983: 5v) oopgemaak vir die erkenning dat die doop nie die teken en seël van die (monopleuriese) genadeverbond en die beloftes daarvan is nie, maar teken van die geloofsbeslissing van die (volwasse) individu. Die gelowige kry op grond van sy geloofsbeslissing deel aan die erfenis wat die dood van Jesus Christus meebring. Hiermee word die "eensydigheid" van God se genadeverbond geweld aangedoen. Pont beroep hom in dié verband op Johannes Behm se eweneens logosentriese studie van die Griekse woorde diatithemai en diathe $\bar{e} \bar{e}$ in Kittel/Friedrich se teologiese woordeboek van die Nuwe Testament. Behm (1971: 134) formuleer sy samevattende definisie van die "betekenis" van $b^{e}$ rit-diathēké soos volg: "Diathe $\bar{e} \bar{e}$ is from first to last the 'disposition' ('Verfügung' - AG v A) of God, the mighty declaration ('Bundgebung' - AG v A) of the sovereign will of God in history, by which He orders the relation between Himself and men according to His own saving purpose ('Heilsabsicht' - AG $\mathrm{v} A$ ), and which carries with it the authoritative divine ordering ('got- 
tliche Verordnung/Stiftung' - AG v A) ...." Die saak word egter nog meer problematies as Behm se pas voorafgaande opmerkings, waarby Ernst Kutsch in 'n omvattende woord- en eksegetiese studie van $b^{e}$ rit en diathe $\bar{k} \bar{e}$ sterk aansluit, ook in ag geneem word: "In both form and content the NT use of diathe $\bar{e} \bar{e}$ follows that of the OT. the only difference is to be found in the step from prophecy to fulfilment. One can hardly say that the NT takes the same course as the LXX and introduces religious thoughts into the legal word, so that it is a 'testament and yet not a testament' (aanhaling van Ernst Lohmeyer - AG v A). Nor can one refer to a transformation of the covenant concept to include that of a testament. Neither 'covenant' nor 'testament' reproduces the true religious sense of the religious term 'diathēkē' in the Greek Bible" (Behm 1971: 134; kursivering deur my).

Dit het op hierdie punt van ons ondersoek nodig geword om vervolgens eers duidelikheid in verband met die semantiek van diathēkē en betekenisverwante woorde in die Nuwe Testament te kry. Dit is noodsaaklik, omdat ' $n$ bepaalde tendens in die debat oor die verband tussen kinderdoop en verbond al hoe meer in ons ondersoek vorendag gekom het, naamlik dat taalkunde dikwels op ' $n$ illegitieme wyse met teologie vermeng word, sowel as taalkundige kategorieë en argumente op sigself.

\section{'N SEMANTIESE ONDERSOEK VAN TERSAKE WOORDE}

Hierdie deel van ons studie bestaan uit twee aspekte: Eerstens probeer ons ' $n$ semantiese verklaring bied vir die verwysing van die woord testament in die benaminge "Ou Testament" en "Nuwe Testament" na onderskeidelik "Ou Verbond" en "Nuwe Verbond", terwyl die woord testament self ' $n$ forensiese betekenis het teenoor "verbond" wat die betekenis het van "interpersoonlike ooreenkoms". Die verklaring wat ons hiervoor gaan aanbied, is die resultaat van 'n diakroniese, semantiese studie. Tweedens bied ons kortliks 'n oorsig van die onderskeidende betekeniskomponente van die woorde en uitdrukkinge in die Nuwe Testament wat semanties gesien met 'n "verbondsverhouding" te doen het. Hierdie uiteensetting is aan die ander kant die resultaat van 'n sinkroniese, semantiese studie.

Die Griekse selfstandige naamwoord diathēke of die werkwoord diathithemai in die Nuwe Testament het semanties drie verskillende betekenismoontlikhede (= "noempotensies"). Twee hiervan is deel van die breë semantiese domein "assosiasie", oftewel "relasionele verhou- 
dinge". Sommige woorde in hierdie semantiese woordveld word in kontekste gebruik wat te doen het met die teologiese konsep van verbondsverhouding tussen God en mens (kyk later). Die ander betekenismoontlikheid van diathēké/diatithemai is deel van 'n ander breē semantiese domein wat te doen het met eienaarskap/juridiese besittingsreg en die reg van die oordrag daarvan. Die diagnostiese betekenis-komponent wat diathe ke/e/diatithemai in laasgenoemde semantiese woordveld onderskei van die ander woorde, wat generies tot dieselfde domein hoort, is dié van 'n juridiese dokument waarin en waardeur ' $n$ erfenis deur 'n besitter aan ' $n$ benoemde erfgenaam bemaak word en wat by die dood van die besitter in funksie tree, dit wil sê 'n "testament". Die selfstandige naamwoord diathēke en die werkwoord diatithemai doen diens vir hierdie betekenismoontlikheid in respektiewelik Heb 9: 16 en Heb 9: 17. (Gal 3: 17 en die so genoemde nagmaalswoorde in Mark 14: 24 en Matt 26: 28 is gedeeltes waar die spesifieke noempotensie van diathe $\bar{k} \bar{e}$, as gevolg van uiteenlopende interpretasies in die geskiedenis van die eksegese van hierdie gedeeltes, omstrede is). In enkele ander gedeeltes in die Nuwe Testament kom die uitdrukking diathe $\bar{e} \bar{e}$ kaine $\bar{e}$ voor, te wete die nagmaalswoorde in 1 Kor 11: 25 en Luk 22: 20, asook in 2 Kor 3: 6 en Heb 9: 15. Hierdie gedeeltes het Jer 31: 31-34 of Eks 24: 8 as agtergrond. In 2 Kor 3: 6 funksioneer die uitdrukking diathe $\bar{k} \bar{e}$ kain $\bar{e}$ teenoor diathe $\bar{k} \bar{e}$ palaia en in Heb 9: 15 teenoor diathe $\bar{k} \bar{e}$ prōte in dieselfde vers. Die volgende uitdrukkings funksioneer in dieselfde verband: diathēke kreittōn (Heb 7: 22 en 8: 6), diathēkē nea (Heb 12: 24) en diathēkē aiōnia (Heb 13: 20). In al hierdie passasies het ons egter nie met die noempotensie "testament" in die juridiese betekenis te doen nie, en het die nuwe Afrikaanse Bybelvertaling die woord diathe $\bar{e} \bar{e}$ in al hierdie gevalle dus korrek met "verbond" vertaal.

Wat Heb 9: 16 en 9: 17 betref, waar diathēke/diatithemai "testament" beteken, is ongetwyfeld ' $n$ doelbewuste woordspel met die ander betekenismoontlikheid van diathēke aanwesig, naamlik "verbond" wat twee keer in Heb 9: 15 voorkom en betrekking het op die kontras "eerste verbond" - "nuwe verbond". (Die werkwoord diatithemai het in Heb 8: 10 die betekenis "verbond".) Strathmann (1970: 124), onder andere, verwys soos volg na hierdie "Sachverhalt" tussen "testament" en "verbond": "Auffällig ist ... dass vom dem Tod trotzdem ... als von einem eintretenden Ereignis gesprochen wird. Dies aber hängt mit der Doppelsinnigkeit des griechischen Wortes für 'Bund' (diathēkē) zusammen, vermöge deren es zugleich 'Testament' bedeutet ... Der Ü- 
bersetzer kann diesem Sachverhalt nur dadurch gerecht werden, dass er in V.16 und 17 jenes Wort mit 'Testament' wiedergibt, aber von V.18 an wieder zu der Bedeutung 'Bund' zurückkehrt'.

Dit laat die vraag ontstaan of die Ou-Testamentiese verbondsidee (kyk veral Eks 24: 8 en Jer 31: 31-34) wat in die Nuwe Testament op hierdie wyse in onder andere die Hebreërbrief heropgeneem is, nie tog na 'n "testament-struktuur" verander het of ten minste dit begin insluit het nie. Hierdie vraag is nie net in die lig van die teologiese debat oor die kinderdoop-verbond (kyk weer die uiteenlopende beredeneringe hieroor by Pont en König hierbo met betrekking tot die monopleuriese aard van die genadeverbond) relevant nie, maar ook in die lig van die semantiese probleem dat die woord diathe $\bar{e} \bar{e}$ in der waarheid in die klassieke sowel as Hellenistiese Grieks dieselfde beteken as die Latynse, juridiese woord testamentum (kyk Kutsch 1978: vii; hy, bls 52-6, maak melding van slegs enkele gevalle in buite-Joods-Griekse literatuur waar diathēkē nie "testament" beteken nie). Soos reeds vermeld, kom diathêké in die Nuwe Testament bo alle twyfel net twee keer (in die Hebreërbrief) met die betekenis "testament" voor, teenoor die een en dertig keer (indien die drie omstrede gevalle ingesluit sou word) met die betekenis "verbond". In buite-Bybelse, Griekse literatuur word die woord sunthēke vir "verbond" gebruik. Hierdie woord kom nie in die Nuwe Testament voor nie, en die werkwoord suntithemai wat wel in drie Nuwe-Testamentiese gedeeltes voorkom, het niks met 'n verbond tussen God en mens te doen nie. Dit is dus merkwaardig dat NuweTestamentiese skrywers in aansluiting met die Septuagint die woord diathēke meestal met die betekenis "verbond" aanwend. In die Septuagint is diathe $\bar{e} \bar{e}$ in al die gevalle, behalwe in Gen 14: 13 en 1 Kon 11: 11, die vertalingsekwivalent van die Hebreeuse $b^{e}{ }^{e} \bar{t}$. (Benewens $b^{e} r \bar{t}$ is enkele ander woorde en uitdrukkings ook met diathe $\bar{k} \bar{e}$ in die Septuagint weergegee - kyk Kutsch 1978: 58v.) Watter verklaring kan gebied word vir hierdie verskynsel dat die Griekse, juridiese woord diathēke in die Septuagint as vertalingsekwivalent van die Hebreeuse $b^{e}{ }^{r i t}$ (= verbond) gebruik is, en as sodanig in die Nuwe Testament en in JoodsGriekse, religieuse literatuur meestal vir die betekenis "verbond" diens begin doen het. Die woord $b^{e}$ rit self het nêrens in die Ou Testament of in enige ander Hebreeuse teks wat bekend is, die juridiese betekenis "testament" nie. In hierdie verband is dit interessant om daarop te let dat die Vetus Latina-vertalings die Hebreeuse woord $b^{e}$ rit met testamentum weergegee het wat, soos reeds vermeld, dieselfde as diathe $\bar{e} \bar{e}$ beteken. Hieronimus het aan die ander kant $b^{e} r \bar{t} t$ in Latyn vertaal met 
foedus of pactum en Aquilla wat bekend is vir sy letterlike vertaling van die Hebreeuse grondteks in Grieks, het sunthe kē as vertalings-ekwivalent gebruik. Die Septuagint wat soms heelwat interpretasie bevat, se vertaling van $b^{e}$ rit met diathe $\bar{e} \bar{e}$, soos in die Oud-Latynse vertalings daarvan met testamentum, kan verklaar word in die lig van die twee komponente wat testamentum/diathe $\bar{k} \bar{e}$ bevat. Die een komponent kan as 'n "supplementêre" komponent bestempel word, en die ander een as die "diagnostiese" komponent (kyk Nida \& Taber 1974: 77). Die "diagnostiese komponent" van diathe $\bar{e} \bar{e}$ is die laaste beskikkingsreg van 'n erflater in 'n juridiese dokument met betrekking tot die oordrag van sy besittings by sy dood aan 'n erfgenaam. Die "supplementêre komponent" is dié van monopleuriese beskikkingsreg, in die sin van dat die testateur alléén beskik. Wat die laasgenoemde komponent betref, is die Hebreeuse woord $b^{e}$ rit in 'n sekere sin wel 'n vertalings-ekwivalent van diathēke, omdat die aspek "monopleuriese beskikking" deel is van die "diagnostiese komponent" van die Hebreeuse $b^{e}$ rit en nie van die Griekse sunthēkē nie. Toe die Septuagint-vertalers diathēké as vertalings-ekwivalent van $b^{e}$ rit gekies het, wou hulle dus heelwaarskynlik op só 'n wyse die "monopleuriese beskikking" van God in sy verbond met Israel "vertaal". In hierdie gevalle is die aanvanklike "diagnostiese komponent" met 'n "supplementêre komponent" verruil. Die juridiese beskikkingsreg is met ander woorde deur die monopleuriese verbondsverhouding in die skadu gestel en selfs vervang. In die letterlike sin van die woord het sekere Nuwe-Testamentiese skrywers, en ander skrywers van Joods-Griekse literatuur, in aansluiting by die Septuagint die woord diathêke in die betekenis van "verbond" begin gebruik. "Das ist nicht verwunderlich. Denn die christliche Urgemeinde wusste sich in der Tradition des Alten Testament lebend; sie hat mit wichtigen theologischen Aussagen auch Begriffe, termini technici, aus der Bibel des zeitgenössischen Judentums, die auch ihre heilige Schrift war, aufgenommen. Das gilt sicherlich auch für die aramaïschsprechenden Gemeindeglieder, vor allem aber für die, deren Muttersprache oder doch wenigstens Umgangssprache das Griechische war. $\mathrm{Zu}$ diesen übernommenen Begriffen gehört auch das Substantiv diathēke" (Kutsch 1978: 87).

Twee konklusies kan uit bovermelde verklaring getrek word: Enersyds moet aanvaar word dat die benaminge "Ou Testament" en "Nuwe Testament", as aanduiding van die boeke van respektiewelik die "Ou Verbond" en die "Nuwe Verbond", saaklik ontleen is aan die Pauliniese uitdrukking in die nagmaalsoorlewering sowel as dié in die Hebreër- 
brief, naamlik diathēkē kaine- diathēkē palaia/protē. Dit het fraseologies geyk geraak as gevolg van die Oud-Latynse vertalings novum testamentum-vetus testamentum. Andersyds is dit in die lig van die gemelde diakroniese, semantiese agtergrond duidelik dat die testament-komponent in Heb 9: 16 en 17 nie die monopleuriese inisiatief van God in sy verbond (Heb 9: 15) met die verloste mens uitwoeker nie.

Die fout moet met ander woorde nie gemaak word om te meen dat die betekenis van diathēkē/diatithemai in alle aktuele gebruiksgevalle "verbond" èn "testament" verenigd beteken nie. Dit is ò die een óf die ander (kyk respektiewelik Heb 9: 15 en Heb 19: 16 en 17). Indien die eksegeet sou meen dat diathēke telkens vir beide noempotensies verenigd diens doen, begaan hy die taalkundige dwaling wat James Barr (1961: 218) "illegitimate totality transfer" noem. Die semantiese grondstelling moet altyd in ag geneem word dat ' $n$ bepaalde woord, soos diathēké/diatithemai, in ander verbande vir ander betekenisse diens kan doen. Een en dieselfde woordvorm kan met ander woorde in verskillende woordvelde optree, juis omdat elke woord sy eie betekenisveld besit. ' $n$ Woord kan dus verskillende betekenismoontlikhede (= noempotensies) hê. Dit staan bekend as "polisemie". Hierdie noempotensies maak deel uit van verskillende semantiese domeine (= woordvelde). Dit kom daarop neer dat woorde in sistematiese (struktuele) opposisie met ander woorde staan wat saamwerk aan die simbolisering van ' $\mathrm{n}$ koherente sake-gebied (kyk o.a. Lehrer 18974: 46 en Nida 1975: 32). Hierby moet in ag geneem word dat ' $n$ woord nie identies is aan die "sake-gebied" (= begrip/konsep) waarvan dit deel uitmaak nie. Gewigtige argumente oor teologiese sake/konsepte word dikwels baie maklik op één woord gebou, sonder dat daar eerstens in berekening gehou word dat woorde poliseem van aard is en tweedens dat ' $n$ bepaalde saak deur verskeie noempotensies van verskillende woorde simboliseer word. Elkeen van hierdie noempotensies se "betekenis" in aktuele konteks word beskryf aan die hand van sy diagnostiese betekeniskomponent in relasie met dié van die ander noempotensies in dieselfde "sakegebied". Dit is belangrik om ook in gedagte te hou dat "betekenis" egter meer is as die blote "betekenis" van woorde. Met die konteks moet deeglik rekening gehou word. Die sin, die perikoop, die hoofstuk, die hele boek en nog veel meer is mede-bepalend vir "betekenis".

Die "verbondstruktuur" in die Nuwe Testament behoort met inagneming van ons insigte vandag op onder andere die terrein van die semantiek, soos hierbo kortliks aangedui, beskryf te word. Só 'n beskrywing kan kriteria help bied vir die evaluering van teologiese kwes- 
sies wat spruit uit die debat oor die verhouding kinderdoop-verbond. Dit kan miskien in die toekoms "premature theological evaluations of biblical linguistic data" (vgl Barr 1972: 18) voorkom.

Ons het vroeër daarop gewys dat die Griekse woord diathēkē drie betekenismoontlikhede in die Nuwe Testament het waarvan twee deel is van die breë semantiese domein "assosiasie"/"relasionele verhoudinge". Hierdie woordveld het te doen met daardie "sake-gebied" waarop die verbondsteologie betrekking kan hê. (Dié teologiese konsep kan egter ook verband hou met ander semantiese domeine, soos "groepe mense" wat onverdeel in drie sub-domeine: sosio-religieuse groepe, sosio-politiese groepe en sosiale groepe.) Die woordveld "assosiasie"/"relasionele verhoudinge" bestaan uit heelwat sub-domeine. Dié een waarvan diathēkē/diatithemai se twee noempotensies deel is, het betrekking op die aangaan/sluit of bevestiging van 'n ooreenkoms. Die ander Griekse woorde en uitdrukkinge in die Nuwe Testament wat saam met diathēke/diatithemai hierdie woordveld vorm, is dexias didōmi (kyk Gal 2:9), asunthētos, on (kyk Rom 1:31), arneomai en aparneomai (kyk Luk 12:9), dikaioo ${ }^{-\mathrm{a}}$; dikaiōsis $^{\mathrm{a}}$ en dikaiosune ${ }^{-\mathrm{b}}$ (kyk respektiewelik Rom 3:24, Rom 4:25 en Rom 1:17) en dikaios ${ }^{b}$, a, on (kyk Rom 1:17).

Twee van hierdie woorde/uitdrukkings word kontekstueel nie gebruik as aanduiding van 'n "relasie" tussen God en mens nie, te wete die idioom dexias didōmi en die adjektief asunthētos, on. Eersgenoemde se "letterlike betekenis" is "regter hande gee". Dit is egter ' $n$ idiomatiese uitdrukking wat betrekking het op die gewoonte om hande te skud en inderdaad dan beteken om 'n ooreenkoms aan te gaan. In Gal 2:9 word hierdie idioom gebruik as aanduiding van die bekende ooreenkoms oor die heidensending tussen die apostels Petrus, Johannes en Jakobus aan die een kant en Paulus aan die ander kant. Wat die adjektief asunthētos, on betref, is die handeling in fokus van iemand wat hom nie gebonde ag aan 'n aangegaande ooreenkoms nie. Paulus gebruik hierdie woord saam met ander in Rom 1:31 om die heidene te beskryf as mense wat onder andere gewetenloos is, onbarmhartig, ongeërg ten opsigte van hulle verpligtinge as gevolg van 'n ooreenkoms, ensovoorts. Die woorde arneomai en aparneomai wat in Luk 12:9 in respektiewelik die protasis en apodosis van 'n partisipiale voorwaardesin voorkom, het betrekking op daardie handeling wat ' $n$ aangegaande ooreenkoms ontken in die sin dat die een ontken dat hy van die ander weet. Die woord aparneomai is bloot die intensivering van arneomai. In Luk 12:9 gaan dit om 'n "verhouding" tussen Jesus en sy volgelinge en Jesus se waarskuwing teen potensiële ontrouheid. Motiewe in verband 
met 'n "verbond', in kontinuering van dié tussen God en Israel, is by wyse van afgeleide teologisering vanuit die geheel-konteks van die Lukasevangelie inderdaad hier moontlik aanwesig. Die rede hiervoor is dat Jesus se volgelinge, besonderlik wat die Lukasevangelie betref (kyk Kingsbury 1981: 122v), aangebied word as die "ware Israel". Motiewe in verband met die doop-praktyk is hier egter heeltemal afwesig en teologisering oor die verhouding doop-verbond op grond van die betekenis van die woorde arneomai en aparneomai sou onses insiens nie verantwoordbaar wees nie. Dit geld egter nie in dieselfde mate van die groep woorde dikaiō, dikaiōsis, dikaiosunē en dikaios nie.

Behalwe die adjektief dikaios, $a$, on het al bogenoemde woorde betrekking op ' $n$ handeling van een party wat ' $n$ ander in die regte verhouding met hom stel, en dit is tipiese Pauliniese taalgebruik. Daar is eksegete wat hierdie handeling forensies verstaan, dit wil sê die daad om regverdig verklaar te word. Dit is egter meer waarskynlik dat Paulus hierdie uitdrukkinge in verband met 'n "verbondsverhouding" tussen God en die verloste mens in Jesus Christus gebruik. Die ondersoek van kontekste en gebruike van hierdie woorde in die Pauliniese literatuur kan derhalwe vir ons studie belangrik wees. Dit is inderdaad teologies legitiem om 'n verband te lê tussen die wyse waarop Paulus teologiseer oor die doop, die regte verhouding met God op grond van die geloof in Jesus Christus (kyk Rom 6: 1-14) sowel as oor die verhouding "ou verbond"-"nuwe verbond" (kyk 2 Kor 3: 1-18 en Gal 3: 15-29) en dié waarop die Hebreërbrief Jesus Christus se verlossingswerk aanbied as die vervulling van die "ou verbond" en die aanbreek van die "nuwe verbond" (kyk Heb 8: 6 en 9). Dit is dan ook geen verrassing nie dat heelwat Nuwe-Testamentici, op grond van onder andere Paulus se taamlik kontinue lyn van beredenering vanaf Rom 3: 21 tot 6: 14 en verder, enersyds 'n verband aflei tussen doop en verbond en andersyds die uitdrukking dikaiosune theou verstaan as verwysend na God se getrouheid met betrekking tot sy beloftes aan Abraham. Wanneer gelet word op die feit dat Jesus Christus in al die tersake kontekste eksplisiet of implisiet die "medium" is op grond waarvan die gelowige in die regte verhouding met God gestel is, kan in der waarheid met stelligheid geponeer word dat daar ' $n$ verband bestaan tussen onder andere die geloof in Jesus Christus (Rom 1: 17), die verlossing deur Jesus Christus (Rom 3: 24), die opstanding van Jesus Christus (Rom 4:25) en die regte (verbonds-)verhouding met God. Hierbenewens kan daar 'n teologiese verband gelê word tussen doop en verbond. In Rom 6: 1-14 sien Paulus die doop as die "afbeelding" van aan 
die een kant die mens se korporatiewe deelhê aan die sterwe en opstanding van Jesus Christus, en aan die ander kant die mens se nuwe gehoorsame lewe in diens van God. In onder andere Rom 1: 17 word hierdie "lewe" as iets $e k$ pisteōs beskryf. Dit is ondenkbaar dat 'n mens jou kan voorstel dat Paulus in die lig van bogenoemde beredenering die verhouding doop-geloof aan alleen die menslike daad en antwoord op die genade van God sou koppel, teenoor kruis-opstanding as alléén God se handeling. Dit is onses insiens korrekte teologisering om die doop te beskou as "sakramentele representasie" van die kruis/opstanding - verlossing/lewe as ' $n$ verenigde relasionele gebeurtenis tussen God en mens. (En sulke formulering het met sinergisme niks te doen nie.) Om die kinderdoop op grond van Rom 6: 4 uit die kerklike praktyk uit te ban, is nie verantwoordelike teologie nie.

Die adjektief dikaios, $a$, on wat onder andere ook in Rom 1: 17 voorkom, verskil van die vorige groep, betekenisverwante woorde daarin dat dit die staat van om in die regte verhouding met God gestel te wees, teenoor die handeling, aandui.

Dit het algaande duidelik geword dat dit veral die dikaiosune $\bar{e}$-betekenisverwante woorde en die twee noempotensies van diathe $\bar{e} \bar{e}-$ /diatithemai is wat in die Nuwe Testament op die verbondsverhouding tussen God en mens betrekking het. Daar bestaan slegs 'n graad verskil in die onderskeie diagnostiese betekeniskomponente tussen diatithemai/diathe $\bar{k} \bar{e}^{\mathrm{a}}$ (kyk resp Heb 8: 10; Hand 3: 25 en Rom 11: 27) en diathe $\bar{e} \bar{e}^{\mathrm{b}}$ (kyk Gal 3: 15). Eersgenoemde het te doen met die sluiting van 'n plegtige ooreenkoms/verbond met resiproke voordele en verpligtinge. Laasgenoemde fokus op die verbale inhoud van 'n sodanige ooreenkoms/verbond. Gesamentlik gesien kom diathēkē met bogenoemde betekenis een en dertig keer in die Nuwe Testament voor. Dit kan in vier groepe tekste onderverdeel word (kyk Kutsch 1978: 91): (1) Die Pauliniese briewe: Rom 9: 4; 11: 27; 1 Kor 11: 25; 2 Kor 3: 6 en 14; Gal 3: 15 en 17, 4: 24 (2) Die Hebreërbrief: Heb 7: 22; 8: 6, 8, 8, 9, 10; 9: $4,4,15,15,16,17,20 ; 10: 16,29 ; 12: 24$ en 13: 20 (3) Die LukasHandelinge korpus: Luk 1: 72; Hand 3: 25 en 7: 8 (4) Die oorlewering van Jesus se nagmaalswoorde: Mark 14: 24; Matt 26: 28; Luk 22: 20 en 1 Kor 11: 25. Afgesien van hierdie groepe tekste, is daar nog Ef 2: 12 en Op 11: 19. Dit is opvallend dat die woord diathe $\bar{k} \bar{e}$ nie voorkom in die Sinoptiese Evangelies (die nagmaalswoorde uitgesluit), die Johannese literatuur, die Pastorale briewe en die Algemene briewe nie. Sy voorkoms blyk dus baie lokaal te wees in die teologiese strominge van die Nuwe-Testamentiese kerk. 
'n Deursnit-ondersoek van al diathēkē se gebruiksgevalle in die Nuwe Testament toon aan dat dit veral in twee gebruiks-areas funksioneer (kyk Kutsch 1978: 159v): as gawe van God èn as eis van God. Wat laasgenoemde betref, is Gal 4:24 'n goeie voorbeeld, omdat hierdie Skrifgedeelte Eks 24: $7 \mathrm{v}$ as agtergrond het: Moses eis op grond van die wet van God gehoorsaamheid by die volk. In hierdie verband is dit opvallend dat selfs die besnydenis-gebod, in aansluiting met Gen 17: $10 \mathrm{vv}$, in Hand 7: 8 as diathe $\bar{k} \bar{e}$ aangedui word. Die woord diathe $\bar{e} \bar{e}$ funksioneer egter in die meeste Nuwe-Testamentiese gevalle as 'n verwysing na God se gawe. Die uitdrukking diathēkai tēs epangelias (nav: "verbonde en die beloftes wat daarmee saamhang") in Ef 2: 12 is hiervan 'n goeie voorbeeld. (Dieselfde jukstaposisie van diathe $\bar{e} \bar{e}$ en hai epangeliai kom onder andere ook in Gal 3:16v voor.) Met die koms van Jesus Christus (vgl Hand 3:25v) het ook die heidene hieraan deelgekry (Ef 2: 13v).

Dit blyk dat veral twee tipe Ou-Testamentiese verwysings na God se verbond belangrik was in die Nuwe-testamentiese kerk se teologieë wat dit daarom heropgeneem en herinterpreteer het: die uitdrukking

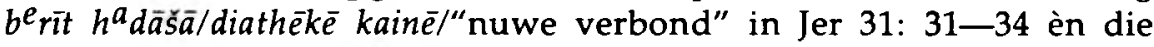
uitdrukking dam-hab ${ }^{e} \overline{r i t} /$ haima tēs diathēkēs/die "bloed van die verbond" in Eks 24: 8. Die gemeenskaplike element van die Nuwe-Testamentiese gebruik van hierdie twee motiewe is dat die dood van Jesus versoenende werking het (vgl resp Heb 9: 19-21 en Mark 14: 24; Matt 26: 28). Die twee tradisies in die Nuwe Testament wat die meeste van die motief "ou verbond" "nuwe verbond" gemaak het, is Paulus en die skrywer van die Hebreërbrief (vgl Kutsch 1978: 161). Eersgenoemde gebruik sterker uitsprake in verband met'n tipe diametrale verhouding daartussen. Volgens Paulus het die "nuwe verbond" die "ou verbond" met die vervulling in Jesus Christus vervang. Tog sal dit 'n geweldige oorspanning van die bedoeling van die onderskeie kontekste wees indien daar op grond van Paulus se polemiek met Judaïserende elemente (die historiese agtergrond van sy beredenering in hierdie verband) ' $n$ diskontinuïteit tussen die Ou Testament en die Nuwe Testament as sodanig afgelei sou word. Insgelyks sou dit ook nie verantwoordbaar wees nie om Israel as Ou-Testamentiese volk van God en die Christelike kerk van die Nuwe Testament as twee diametrale groothede te onderskei op grond van Paulus en die skrywer van die Hebreërbrief se allegoriserende midrash rakende die verhouding "ou verbond"-"nuwe verbond". Die teologiese vraagstuk oor die kontinu1"teit al dan nie tussen Israel en die kerk, sowel as dié tussen die $\mathrm{Ou}$ 
Testament en die Nuwe Testament, sal met argumente hanteer moet word wat op baie meer as net die "verbondsleer" gebou is.

Dit bring ons ten slotte by die oortuiging dat die "verbondsleer" nie op 'n positivistiese wyse hermeneuties as Beziehungsmitte van die totale Bybelse boodskap gebruik mag word nie. Die woord diathēke, en daarby ook dikaiosun $\bar{e}$, word ontoelaatbaar oorspan wanneer dit ingespan word om Testamente, Bybelboeke en Bybelse temas met mekaar te laat harmonieer om sodoende op 'n heuristiese wyse antwoorde op bykans alle teologiese vrae te gee. Dié oor die geldigheid van die kinderdoop al dan nie, is hierby ingesluit.

\section{SLOTOPMERKINGS}

Teologiese kwessies soos die volgende het uit die debat oor die verhouding kinderdoop-verbond gespruit en dit behoort in 'n volgende studie deeglik aan die hand van soveel moontlike eksegetiese gegewens, met die inagneming van die semantiese besonderhede van onder andere hierbo, ondersoek en getoets te word:

1. Die monopleuriese aard van God se verbond met die mens "in Christus".

2. Die verhouding tussen die Ou-Testamentiese Israel en die NuweTestamentiese kerk met betrekking tot enersyds die verband "ou verbond"-"nuwe verbond" en andersyds die "korporatiewe" aard van die verbond teenoor individualisme.

3. Die beloftes van die verbond, en die geloof as eis in die verbondsverhouding met God.

4. Die verhouding kruis-doop met betrekking tot enersyds die aangeleentheid "sakramentele representasie" en andersyds die verband doop-nagmaal.

5. Die "teken en seël" van die verbond en sy beloftes in die Nuwe Testament.

\section{Literatuurverwysings}

BARR, J 1961. The semantics of biblical language. London: Oxford University Press.

BARR, J 1972. Semantics and biblical theology. A contribution to the discussion, in Supplements to Vetus Testamentum. (Congress Volume 22). Leiden: Brill.

BARTH, K 1936. Volkskirche, Freikirche, Bekenntniskirche. Evangelische Theologie. (Aangehaal deur GC Berkouwer 1947. Karl Barth en de kinderdoop. Kampen: Kok).

BARTH, K 1947a. Die kirchliche Lehre von der Taufe. Theologische Studien 14, 3-48.

BARTH, K 1947b. Botschaft von der freien Gnade Gottes. Theologische Studien 23, 2-28.

BARTH, K 1948. Die christliche Lehre nach dem Heidelberger Katechismus. Zürich: Zollikon.

BARTH, K 1958. Die Lehre von Gott, in Die Kirchliche Dogmatik II, 1. Vierte Auflage. Zollikon: Evangelischer Verlag. 
BARTH, K 1967. Die Taufe als Begründung des christlichen Lebens, in Die kirchliche Dogmatik IV, 4. Zürich: EVZ-Verlag.

BARTH, K 1969. Die Lehre von der Schöpfung, in Die Kirchliche Dogmatik III, 4. Dritte Auflage. Zürich: EVZ-Verlag.

BEHM, J 1971. Diatithemi, diathēke, in Kittel, G \& G Friedrich (ed) 1971. Theological dictionary of the New Testament. Volume II. (Translator and editor: GW Bromiley). Fourth printing. Grand Rapids, Michigan: Eerdmans, 104-34.

BERKHOF, L 1946. Systematic Theology. Grand Rapids, Michigan: Eerdmans.

BERKOUWER, GC 1947. Karl Barth en de kinderdoop. Kampen: Kok.

BERKOUWER, GC 1974. Een halve eeuw theologie. Motieven en strominge van 1920 tot heden. Kampen: Kok.

ENGELBRECHT, BJ 1983. Verband tussen doop en verbond mag nie deurgesny word nie. Die Hervormer Jrg 75/8, 1.

FLESSEMAN-VAN LEER, E (ed) 1980. The Bible. Its authority and interpretation in the ecumenical movement. Geneva: World Council of Churches. (Faith and Order Paper No. 99).

HEYNS, JA 1978. Dogmatiek. Pretoria: NG Kerkboekhandel.

JASPERT, B (ed). Karl Barth-Rudolf Bultmann letters 1922-1966. (Translated and edited by GW Bromiley). Grand Rapids, Michigan: Eerdmans.

JONKER, WD 1984. Die doop sê: Ek sal vir jou 'n God wees. Die Kerkbode Jrg 136/8, 7 en 12.

KÖNIG, A 1971. Karl Barth se finale verwerping van die kinderdoop. Theologia Evangelica $4 / 1,44-45 ; 4 / 2,118-29$.

KÖNIG, A 1983. Die kinderdoop en die genadeverbond. Ongepubliseerde voordrag voor 'n teologiese kongres oor die kinderdoop, Universiteit van Suid-Afrika 3-5 Oktober 1983.

KUTSCH, E 1978. Neues Testament-Neuer Bund? Eine Fehlübersetzung wird korrigiert. Neukirchen-Vluyn: Neukirchener Verlag.

LEHRER, A 1974. Semantic fields and lexical structure. Amsterdam: North-Holland.

NIDA, EA \& CR Taber 1974. The theory and practice of translation. Leiden: Brill.

NIDA, EA 1975. Componential analysis of meaning. An introduction to semantic structures. Den Haag: Mouton.

PONT, AD 1983. Die kinderdoop en verbond. 'n Voorlopige terreinverkenning. Ongepubliseerd. Universiteit van Pretoria.

STRATHMANN, H 1970. Der Brief an die Hebräer, in Jeremias, J \& H Strathmann. Die Briefe an Timotheus und Titus. Der Brief an die Hebräer. Göttingen: Vandenhoeck \& Ruprecht, 69-158. (NTD 9).

VAN RULER, AA 1945. Kerk en verbond, in Religie en politiek. Nijkerk: Callenbach, 69-86.

VISSER, LLJ 1958. Die verbond in die teologie van Karl Barth. Stellenbosch: Universiteit van Stellenbosch. (Ongepubliseerde doktorale proefskrif). 